\title{
The Benefits of Holistic Therapy for Psychological Disorders in Postpartum Mother: A Systematic Review
}

\author{
Syafrida Ainur ${ }^{1 *}$, Lucky Herawati ${ }^{2}$, Melyana Nurul Widyawati ${ }^{1}$ \\ ${ }^{1}$ Poltekkes Kemenkes Semarang, Semarang, Indonesia \\ ${ }^{2}$ Poltekkes Kemenkes Yogyakarta, Yogyakarta, Indonesia \\ * frida.sya@gmail.com
}

\begin{abstract}
Physical and psychological changes during postpartum period can make postpartum mother vulnerable to psychological disorders such as anxiety and depression. The purpose of this study was to identify and analyze several holistic therapies that are beneficial for reducing psychological disorders during postpartum period. The inclusion criteria in this study were articles in english; samples in the form of postpartum mothers; and experimental research. There are 12 research articles that included in the analysis of this research, research articles on mindfulness $(n=4)$, massage $(n=4)$, and aromatherapy $(n=$ 4). Holistic therapy can affect the regulation of the nervous system and reduce levels of cortisol hormone. Holistic therapies such as mindfulness, massage, and aromatherapy have been shown to be beneficial for reducing psychological disorders such as anxiety to depression in postpartum mothers which have an impact on increased relaxation and positive mood.
\end{abstract}

Keywords: Aromatherapy, Holistic Therapy, Massage, Mindfulness, Postpartum Women, Psychological Disorders 


\section{STRADA Jurnal Ilmiah Kesehatan}

DOI: $10.30994 /$ sjik.v9i2.524

ISSN: 2252-3847 (print); 2614-350X (online)

Vol.9 No.2 November 2020 Page.1708-1717

\section{BACKGROUND}

The postpartum period is the return of the physiological conditions of the postpartum mother's reproductive organs to conditions as before pregnancy, which begins after the birth of the placenta and will last about 6 weeks (Kementerian Kesehatan, 2013; Jordan, Farley and Grace, 2019).

During the postpartum period, there are various changes both physically and psychologically so that the postpartum mothers need coping and adaptation management to deal and overcome physical and psychological changes. Postpartum mothers also need the attention from the health workers to be able to support their coping and adaptation process (María et al., 2012).

Physical and psychological changes during the postpartum period, as well as taking on roles and responsibilities as a mother for a newborn will make the postpartum mother prone to experiencing psychological disorders such as anxiety and postpartum depression. Research shows that $40 \%$ of postpartum women have high anxiety scores (Field, 2018). Research also shows that $17 \%$ incidence of postpartum depression in postpartum mothers without a history of depression (Shorey et al., 2018).

The risk of maternal psychological disorders during the postpartum period is two times higher than women during other periods. However, psychological disorders of postpartum mothers often go undetected and untreated so that it can have an impact on the general health and well-being of mothers, newborns, and family members (Shorey et al., 2018).

Psychological disorders in postpartum mothers, especially primiparous mothers, can damage the intention, motivation and confidence of mothers to breastfeed that led mothers switch to formula milk (Adedinsewo et al., 2014b; Fallon et al., 2016). Maternal anxiety has been linked to decreased prolactin synthesis. The prolactin hormone is a hormone that functions to stimulate the synthesis of breast milk which includes the production of a number of milk proteins, especially casein. The reduced synthesis of the prolactin hormone will result in a decreased milk production (Adedinsewo et al., 2014a; Agustina, Hadi and Widyawati, 2016).

Mothers that suffer from psychological disorders often show changes in attitudes such as indifference, neglect, and unresponsiveness to their babies. Mothers with psychological disorders are also at increased risk for recurring psychological disorders (Fallon et al., 2016; Shorey et al., 2018).

Therefore, early diagnosis, management, and prevention of psychological disorders in postpartum mothers are needed so that the health and well-being of postpartum mothers, newborns and families can be manifested (Shorey et al., 2018).

The term holistic comes from the Greek word 'O $\lambda$ o $\varsigma_{-}$-holos which means whole and total. Holistic therapy is a therapy approach that views humans as whole beings by paying attention to their biological, emotional, intellectual, social and spiritual aspects. All these aspects are one and cannot be separated, so that if there is a change in every aspect of a person's life, it can bring changes to every aspect of their existence and differentiate the quality of their life. Holistic care is being used as a philosophy on how to approach a good health by creating balance and harmony between body, mind and spirit (Papathanasiou, Sklavou and Kourkouta, 2013).

Holistic therapy not only focuses on the symptoms of the patient but also on the condition of the patient's body, mind, and spirit as a whole. Holistic medicine with natural or alternative medicine can provide effective and efficient healing effects with fewer side effects compared to modern medicine in order to increase health and satisfaction of the 


\section{STRADA Jurnal Ilmiah Kesehatan}

DOI: $10.30994 /$ sjik.v9i2.524

patient (Papathanasiou, Sklavou and Kourkouta, 2013). Midwifery care that carried out using complementary or alternative therapies according to the philosophy of midwifery avoids unnecessary medical interventions and supports women's choice and autonomy (Hall, Mckenna and Griffiths, 2012).

The purpose of this research is to identify and analyze several holistic therapies that have benefits on reducing psychological disorders during postpartum period which expected to produce scientifically accountable information that it can be developed and applied as a policy.

\section{METHODS}

\section{Search Strategy}

The search for articles for this study was carried out by searching the databases of Science Direct, PubMed, Wiley Online Library, and Google Scholar. Only articles that contain full text will be included in this study. The search was carried out by entering the first keywords, such as "psychological disorders" and "postpartum mother", then the second keyword, such as "holistic" and "mind body soul". The search for articles for this study was limited to the last 10 years.

\section{Inclusion and Exclusion Criteria}

The inclusion criteria in this study were articles in English; samples are postpartum mothers; and experimental type of research. While the exclusion criteria in this study were articles that not in English; samples other than postpartum mothers; and non-experimental research.

\section{Data Extraction}

The search for research articles was carried out on July 2020 to August 2020. The author extracts the research articles that have been obtained by recording them in the article screening form. In the article screening form, research articles are screened and analyzed for titles and abstracts to group research articles according to the type of intervention, determine the suitability of the research articles with inclusion and exclusion criteria, and detect duplication of research articles.

The results of the extraction of research articles are written in tabular form containing

article titles, author names, years, methods, and results.

\section{RESULTS}

A search of research articles through the Science Direct, PubMed, Wiley Online Library, and Google Scholar databases resulted in 42 articles that passed the initial screening after entering the first and second keywords. Of the 42 articles, there were 8 articles that were not full text research articles, leaving 34 relevant research articles for screening. After the review was carried out, there were 22 research articles that did not fit the inclusion criteria, such as articles that were not in English $(\mathrm{N}=5)$, the sample did not match the criteria $(\mathrm{N}=10)$, and the type of research was not an experimental $(\mathrm{N}=7)$. After further review, 12 research articles were included in the analysis of this study.

The 12 research articles that were included in the analysis of this study were divided based on the holistic therapy method provided, namely mindfulness $(\mathrm{N}=4)$, massage $(\mathrm{N}=4)$, and aromatherapy $(\mathrm{N}=5)$. 


\section{STRADA Jurnal Ilmiah Kesehatan}

DOI: $10.30994 /$ sjik.v9i2.524

ISSN: 2252-3847 (print); 2614-350X (online)

Vol.9 No.2 November 2020 Page.1708-1717

\begin{tabular}{|c|c|c|c|c|c|}
\hline No. & Title & Authors & Year & Methods & Results \\
\hline 1 & $\begin{array}{l}\text { The } \\
\text { effectiveness } \\
\text { of } \\
\text { mindfulness } \\
\text { training on } \\
\text { reducing the } \\
\text { symptoms of } \\
\text { postpartum } \\
\text { depression }\end{array}$ & $\begin{array}{l}\text { Hajieh } \\
\text { Sheydaei, } \\
\text { Azizreza } \\
\text { Ghasemzadeh, } \\
\text { Amir } \\
\text { Lashkari, } \\
\text { Parvaneh } \\
\text { Ghorbani } \\
\text { Kajani }\end{array}$ & 2017 & $\begin{array}{l}\text { Quasi experimental design. The } \\
\text { sample were } 67 \text { primiparous } \\
\text { postpartum mothers in 2014. The } \\
\text { measurement of depression score } \\
\text { used the Beck Depression } \\
\text { Inventory (BDI), Structured } \\
\text { Clinical Interview and Clinical } \\
\text { Psychological Diagnosis. The } \\
\text { experimental group was given } 8 \\
\text { therapy sessions for } 8 \text { weeks } \\
\text { within } 2 \text { hours. The control group } \\
\text { was given nothing. }\end{array}$ & $\begin{array}{l}\text { There was a significant } \\
\text { difference in the reduction } \\
\text { in depression scores in the } \\
\text { intervention group } \\
\text { compared to the control } \\
\text { group (p 0.001). The mean } \\
\text { pre and post depression } \\
\text { scores in the control group } \\
\text { were } 25.81 \text { and } 25.12 . \text { The } \\
\text { mean pre and post } \\
\text { intervention scores in the } \\
\text { experimental group were } \\
24.75 \text { and 18.5. }\end{array}$ \\
\hline$\overline{2}$ & $\begin{array}{l}\text { Staying Well } \\
\text { during } \\
\text { Pregnancy } \\
\text { and the } \\
\text { Postpartum: A } \\
\text { Pilot } \\
\text { Randomized } \\
\text { Trial of } \\
\text { Mindfulness } \\
\text { Based } \\
\text { Cognitive } \\
\text { Therapy for } \\
\text { the Prevention } \\
\text { of Depressive } \\
\text { Relapse/Recur } \\
\text { rence }\end{array}$ & $\begin{array}{l}\text { Sona } \\
\text { Dimidjian, } \\
\text { Sherryl H. } \\
\text { Goodman, } \\
\text { Jennifer } \\
\text { Felder, Robert } \\
\text { Gallop, } \\
\text { Amanda P. } \\
\text { Brown, Arne } \\
\text { Beck. }\end{array}$ & 2016 & $\begin{array}{l}\text { An experimental study conducted } \\
\text { in } 86 \text { pregnant women with a } \\
\text { history of depression. The } \\
\text { intervention group was given } 8 \\
\text { MBCT sessions for } 8 \text { weeks and } \\
\text { the control group was given } \\
\text { standart treatment. The } \\
\text { measurement of the depression } \\
\text { score used the Edinburgh } \\
\text { Postpartum Depression Scale } \\
\text { (EPDS) and followed up until } 6 \\
\text { months postpartum. }\end{array}$ & $\begin{array}{l}\text { During the postpartum } \\
\text { period, there was a } \\
\text { significant difference in } \\
\text { depression scores in the } \\
\text { intervention and control } \\
\text { groups (p 0.005). The } \\
\text { percentage increase in } \\
\text { depression score was } 4.6 \% \text {, } \\
\text { while in the control group it } \\
\text { was } 34.6 \% \text {. }\end{array}$ \\
\hline 3 & $\begin{array}{l}\text { Feasibility of } \\
\text { a } \\
\text { Mindfulness- } \\
\text { Based } \\
\text { Cognitive } \\
\text { Therapy } \\
\text { Group } \\
\text { Intervention } \\
\text { as an } \\
\text { Adjunctive } \\
\text { Treatment for } \\
\text { Postpartum } \\
\text { Depression } \\
\text { and Anxiety }\end{array}$ & $\begin{array}{l}\text { Barbara } \\
\text { Shulman, } \\
\text { Royce Dueck, } \\
\text { Deirdre Ryan, } \\
\text { Genevieve } \\
\text { Breau, Isabel } \\
\text { Sadowski, } \\
\text { Shaila Misri }\end{array}$ & 2017 & $\begin{array}{l}\text { A quasi-experimental non- } \\
\text { equivalent control group design. } \\
\text { Sample } 31 \text { postpartum mothers } \\
\text { who suffer from depression or } \\
\text { anxiety during the postpartum } \\
\text { period. The intervention group } \\
\text { was given MBCT for } 8 \text { weeks } \\
\text { while the control group was } \\
\text { given standard care. Anxiety } \\
\text { measurement use Generalized } \\
\text { Anxiety Disorder (GAD). }\end{array}$ & $\begin{array}{l}\text { There was a decrease in } \\
\text { anxiety levels from week } 1 \\
\text { to week } 8 \text { in the MBCT } \\
\text { group compared with the } \\
\text { control group ( } \mathrm{p} 0.01 \text { ). In } \\
\text { the control group, anxiety } \\
\text { levels were relatively } \\
\text { constant from week } 1 \text { to } \\
\text { week } 8 \text {. }\end{array}$ \\
\hline 4 & $\begin{array}{l}\text { Postpartum } \\
\text { Outcomes and } \\
\text { Formal }\end{array}$ & $\begin{array}{l}\text { Christina M. } \\
\text { Luberto, Elyse } \\
\text { R. Park, }\end{array}$ & 18 & $\begin{array}{l}\text { Experimental research with a } \\
\text { sample of } 24 \text { primiparous } \\
\text { pregnant women. Modified }\end{array}$ & $\begin{array}{lcr}\text { There was a } & \text { significant } \\
\text { reduction } & \text { in } & \text { anxiety } \\
\text { symptoms } & \text { from } & \text { baseline }\end{array}$ \\
\hline
\end{tabular}




\section{STRADA Jurnal Ilmiah Kesehatan}

DOI: $10.30994 /$ sjik.v9i2.524

ISSN: 2252-3847 (print); 2614-350X (online)

$\begin{array}{ll}\text { Mindfulness } & \text { Janice H. } \\ \text { Practice in } & \text { Goodman } \\ \text { Mindfulness- } & \\ \text { Based } & \\ \text { Cognitive } & \\ \text { Therapy for } & \\ \text { Perinatal } & \\ \text { Women } & \end{array}$

MBCT intervention was given, namely CALM preganancy that conducted for 8 weeks. Anxiety measurements were performed using the Beck Anxiety Inventory (BAI) and the Penn State Worry Questionnaire (PSWQ). The follow up conducted until 3 months of the puerperium. measurement to 3 months of the postpartum period ( $\mathrm{p}$ $<0.003)$. There was a significant reduction in depressive symptoms from baseline measurement up to 3 months of the postpartum period (p 0.001).

Table 1. Articles Reviews : Mindfulness

\begin{tabular}{|c|c|c|c|c|c|}
\hline No & Title & Authors & Year & Methods & Results \\
\hline 1 & $\begin{array}{l}\text { The Effect of } \\
\text { Slow-Stroke } \\
\text { Back Massage } \\
\text { on the } \\
\text { Anxiety } \\
\text { Levels of } \\
\text { IranianWome } \\
\text { n on the First } \\
\text { Postpartum } \\
\text { Day }\end{array}$ & $\begin{array}{l}\text { Fereshteh } \\
\text { Jahdi, } \\
\text { Maryam } \\
\text { Mehrabadi, } \\
\text { Forough } \\
\text { Mortazavi, } \\
\text { and Hamid } \\
\text { Haghani }\end{array}$ & 2016 & $\begin{array}{l}\text { A single blind controlled } \\
\text { clinical study conducted in } 100 \\
\text { primiparous puerperal women } \\
\text { with normal delivery. The } \\
\text { intervention group was given a } \\
\text { slow-stroke back massage } \\
\text { treatment at } 4 \text { to } 18 \text { hours after } \\
\text { delivery for } 20 \text { minutes. In the } \\
\text { control group, postpartum } \\
\text { mothers will only be } \\
\text { accompanied by researchers. } \\
\text { Anxiety measurement was } \\
\text { performed using Spielberger's } \\
\text { state anxiety inventory (STAI) } \\
\text { questionnaire. }\end{array}$ & $\begin{array}{l}\text { There was a statistically } \\
\text { significant difference in } \\
\text { anxiety scores in the } \\
\text { intervention group and the } \\
\text { control group (p 0.001). }\end{array}$ \\
\hline$\overline{2}$ & $\begin{array}{l}\text { The Effect of } \\
\text { Massage } \\
\text { Therapy With } \\
\text { Effleurage } \\
\text { Techniques as } \\
\text { A } \\
\text { Prevention of } \\
\text { Baby Blues } \\
\text { Prevention on } \\
\text { Postpartum } \\
\text { Mother }\end{array}$ & $\begin{array}{l}\text { Desi Sarli, } \\
\text { F. N. Sari }\end{array}$ & 2018 & $\begin{array}{l}\text { A quantitative research with } \\
\text { pre-experimental analytical } \\
\text { research design. The study } \\
\text { sample were } 30 \text { mothers } \geq 7 \\
\text { days to } 6 \text { weeks of the } \\
\text { postpartum period. Samples } \\
\text { were given effleurage massage } \\
\text { treatment twice a week. } \\
\text { Measurement of depression } \\
\text { symptoms used the Edinburgh } \\
\text { Postnatal Depression Scale } \\
\text { (EPDS). }\end{array}$ & $\begin{array}{l}\text { There is a significant } \\
\text { difference in depressive } \\
\text { symptoms before and after } \\
\text { treatment with p value }<0.05 \text {. } \\
\text { Effluerage massage has been } \\
\text { shown to reduce symptoms } \\
\text { of depression by } 20 \% \text { to } \\
80 \% \text {. }\end{array}$ \\
\hline 3 & $\begin{array}{l}\text { Aromatheray } \\
\text { Massage as an } \\
\text { Alternative in } \\
\text { Reducing } \\
\text { Cortisol } \\
\text { Level and } \\
\text { Enhancing }\end{array}$ & $\begin{array}{l}\text { Agustina C.S, } \\
\text { Hadi, } \\
\text { Melyana } \\
\text { Nurul } \\
\text { Widyawati }\end{array}$ & 2016 & $\begin{array}{l}\text { A quasi experimental research } \\
\text { with non-equivalent control } \\
\text { group design. The samples were } \\
44 \text { postpartum mothers divided } \\
\text { into } 4 \text { groups, namely the } \\
\text { massage group, the fennel and } \\
\text { jasmine aromatherapy group, }\end{array}$ & $\begin{array}{l}\text { The mean cortisol levels in } \\
\text { the massage group decreased } \\
\text { from 185.36 } \mathrm{ng} / \mathrm{mL} \text { to } \\
110.55 \mathrm{ng} / \mathrm{mL} \text { after } \\
\text { treatment (p-value 0.004). } \\
\text { The aromatherapy group had } \\
\text { cortisol levels decreased to }\end{array}$ \\
\hline
\end{tabular}




\section{STRADA Jurnal Ilmiah Kesehatan}

DOI: $10.30994 /$ sjik.v9i2.524

Breastmilk

Production on

Primiparous

Postpartum

Women in

Semarang

the aromatherapy massage $115 \mathrm{ng} / \mathrm{mL}$ from $168.18 \mathrm{ng}$ combination group, and the / $\mathrm{mL}$. In the third group control group who were not (combination massage and given any treatment. aromatherapy), cortisol Intervention was carried out levels decreased from 128.36 twice, namely the 3rd and 4th $\mathrm{ng} / \mathrm{mL}$ to $97.9 \mathrm{ng} / \mathrm{mL}$. The day of the puerperium. Anxiety highest decrease in cortisol is measured using the parameter levels occurred in the of the hormone cortisol. massage group (74.82 $\mathrm{ng} /$ $\mathrm{mL})$.

\begin{tabular}{|c|c|c|}
\hline $\begin{array}{l}\text { Effects of } \\
\text { Meridian } \\
\text { Acupressure } \\
\text { Massage on } \\
\text { Body } \\
\text { Composition, } \\
\text { Edema, } \\
\text { Stress, and } \\
\text { Fatigue } \\
\text { in Postpartum } \\
\text { Women }\end{array}$ & $\begin{array}{l}\text { Geum-Sook } 2016 \\
\text { Jung, In- } \\
\text { Ryoung Choi, } \\
\text { Hee-Young } \\
\text { Kang, Eun- } \\
\text { Young Choi }\end{array}$ & $\begin{array}{l}\text { A quasi-experimental research There was a bigger decrease } \\
\text { with a non-equivalent control in psychological stress score } \\
\text { group conductud in } 39 \text { in the experimental group } \\
\text { postpartum mothers who were than in the control group (p= } \\
\text { divided into } 19 \text { mothers in the 0.029). } \\
\text { experimental group and } 20 \\
\text { mothers in the control group. } \\
\text { The intervention was given a } \\
\text { meridian acupressure massage } \\
\text { for } 90 \text { minutes every day for } 5 \\
\text { days. Measurement of stress } \\
\text { scores using a researcher } \\
\text { questionnaire. }\end{array}$ \\
\hline
\end{tabular}

Tabel 2 Articles Reviews : Massage

\begin{tabular}{|c|c|c|c|c|c|}
\hline No & Title & Authors & Year & Methods & Results \\
\hline 1 & $\begin{array}{l}\text { Effectiveness } \\
\text { of } \\
\text { Aromatherapy } \\
\text { Treatment in } \\
\text { Alleviating } \\
\text { Fatigue and } \\
\text { Promoting } \\
\text { Relaxation } \\
\text { of Mothers } \\
\text { during the } \\
\text { Early } \\
\text { Postpartum } \\
\text { Period }\end{array}$ & $\begin{array}{l}\text { Kyoko } \\
\text { Asazawa, } \\
\text { Yoshihiro } \\
\text { Kato, } \\
\text { Ryosuke } \\
\text { Koinuma, Nao } \\
\text { Takemoto, } \\
\text { Shiho Tsutsui }\end{array}$ & 2018 & $\begin{array}{l}\text { A quasi-experimental research } \\
\text { with a two-group pretest-post- } \\
\text { test design conducted in } 242 \\
\text { postpartum mothers. The } \\
\text { participants selected from } 5 \\
\text { essential oils: pure lavender, } \\
\text { ylang-ylang, citron, rosewood, } \\
\text { and sweet orange. Measurement } \\
\text { of the level of relaxation using a } \\
\text { questionnaire from the } \\
\text { researcher. }\end{array}$ & $\begin{array}{l}\text { There was a significant } \\
\text { difference in the level of } \\
\text { relaxation of the postpartum } \\
\text { mother in the intervention } \\
\text { group compared to the } \\
\text { control group (p <0.001). } \\
\text { Giving aromatherapy can } \\
\text { increase the relaxation of } \\
\text { postpartum mothers. }\end{array}$ \\
\hline 2 & $\begin{array}{l}\text { The effects of } \\
\text { clinical } \\
\text { aromatherapy } \\
\text { for anxiety } \\
\text { and } \\
\text { depression in } \\
\text { the high }\end{array}$ & $\begin{array}{l}\text { Pam Conrad, } \\
\text { Cindy Adams }\end{array}$ & 2012 & $\begin{array}{l}\text { The pilot study was } \\
\text { observational with repeated } \\
\text { measurements and samples of } \\
28 \text { postpartum mothers. The } \\
\text { treatment group was divided } \\
\text { into 2, namely the aromatherapy } \\
\text { inhalation group and the }\end{array}$ & $\begin{array}{l}\text { There was a significant } \\
\text { difference in depression } \\
\text { scores based on EPDS and } \\
\text { GAD-7 in the intervention } \\
\text { group and the control group } \\
\text { (p } 0.03 \text { and p 0.02). }\end{array}$ \\
\hline
\end{tabular}




\section{STRADA Jurnal Ilmiah Kesehatan}

DOI: $10.30994 /$ sjik.v9i2.524

ISSN: 2252-3847 (print); 2614-350X (online)

risk

postpartum

woman - A

pilot study

aromatherapy hand technique

group. The treatment was given

in 15 minutes twice a week. The

control group was given

standard care. The measurement

of depression and anxiety

scores used the Edinburgh

Postnatal Depression Scale

(EPDS) and the General

Anxiety Disorders Scale (GAD-

7).

\begin{tabular}{|c|c|c|c|c|}
\hline & $\begin{array}{l}\text { Effect of } \\
\text { Lavender Oil } \\
\text { Aroma in the } \\
\text { Early Hours } \\
\text { of Postpartum } \\
\text { Period on } \\
\text { Maternal } \\
\text { Pains, } \\
\text { Fatigue, and } \\
\text { Mood: A } \\
\text { Randomized } \\
\text { Clinical Trial }\end{array}$ & $\begin{array}{l}\text { Farideh } \\
\text { Vaziri, } \\
\text { Mahsa } \\
\text { Shiravani, } \\
\text { Fatemeh } \\
\text { Sadat } \\
\text { Najib, } \\
\text { Saeedeh } \\
\text { Pourahmad, } \\
\text { Alireza } \\
\text { Salehi, } \\
\text { Zahra } \\
\text { Yazdanpanahi }\end{array}$ & 2017 & 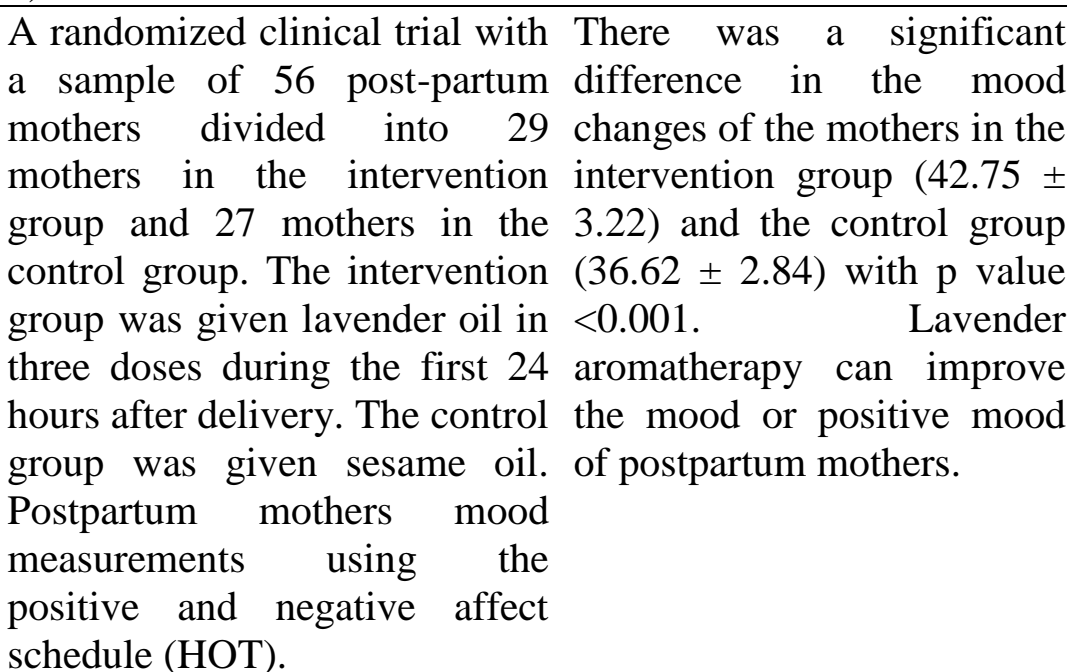 \\
\hline 4 & $\begin{array}{l}\text { Effect of } \\
\text { lavender scent } \\
\text { inhalation on } \\
\text { prevention of } \\
\text { stress, anxiety } \\
\text { and } \\
\text { depression in } \\
\text { the } \\
\text { postpartum } \\
\text { period }\end{array}$ & $\begin{array}{l}\text { Kianpour M, } \\
\text { Mansouri A, } \\
\text { Mehrabi T, } \\
\text { Asghari G }\end{array}$ & 2016 & $\begin{array}{l}\text { A clinical trial with a sample of There was a significant } \\
140 \text { post-partum mothers. The difference in the reduction of } \\
\text { intervention group was given anxiety }(\mathrm{P}=0.012) \text { and } \\
\text { lavender aromatherapy for } 4 \text { depressive symptoms }(\mathrm{P}= \\
\text { weeks, while the treatment } 0.003) \text { in the intervention } \\
\text { group was given standard group compared to the } \\
\text { postpartum care. Measurement control group. } \\
\text { of levels of stress, anxiety, and } \\
\text { depression use the Edinburgh } \\
\text { stress, anxiety, and depression } \\
\text { scale and the } 21-\text { item } \\
\text { Depression,Anxiety, and Stress } \\
\text { Scale (DASS-21 }\end{array}$ \\
\hline
\end{tabular}

Table 3. Articles Reviews : Aromatherapy

\section{DISCUSSION}

The physical and psychological changes that occur during the puerperium make the puerperal mother prone to psychological disorders such as anxiety to postpartum depression (Field, 2018). Psychological disorders in postpartum mothers, especially primiparous mothers, can damage the intention, motivation and self-confidence of the mother to breastfeed which lead into a failure of exclusive breastfeeding (Adedinsewo et al., 2014b; Fallon et al., 2016). Maternal anxiety has been linked to decreased prolactin 


\section{STRADA Jurnal Ilmiah Kesehatan}

DOI: $10.30994 /$ sjik.v9i2.524

ISSN: 2252-3847 (print); 2614-350X (online)

Vol.9 No.2 November 2020 Page.1708-1717

synthesis which results in decreased milk production (Adedinsewo et al., 2014a; Agustina, Hadi and Widyawati, 2016).

Holistic therapy is a therapy that focuses not only on the symptoms felt by the patient but also on the condition of the patient's body, mind, and spirit as a whole. Holistic therapy can provide an effective and efficient healing effect with fewer side effects compared to modern medicine (Papathanasiou, Sklavou and Kourkouta, 2013).

Mindfulness therapy is one of the holistic therapies that aims to increase someone skills in order to be aware, accept, and not judge a condition that occurs to them so that someone will be fully aware and can respond adaptively to various sensations of the body physically, mind, and and emotional (Gu et al., 2015). This will increase the individual's ability to adapt to a problem in a positive manner and increase self-confidence ( $\mathrm{Gu}$ et al., 2015; Sheydaei et al., 2017). Mindfulness can increase the activation of the afferent vagus nerves which affect the medulla oblongata, cerebrum, and limbic system such as decreasing the activation of cortical midline structures and amygdala and increasing activation of the insula and hippocampus, thereby reducing emotional symptoms such as anxiety (Cook-Cottone, 2017).

Mindfulness therapy has been shown to reduce psychological disorders in postpartum mothers such as depression levels (Dimidjian et al., 2014; Sheydaei et al., 2017; Luberto, Park and Goodman, 2018) and anxiety level (Shulman et al., 2017; Luberto, Park and Goodman, 2018) significantly compared to the control group.

Massage will affect the regulation of the autonomic nervous system which has an impact on reducing levels of the cortisol, adrenaline and noradrenaline hormone. Massage also regulates the activity of nerves in the frontal brain and amygdala, and stimulates the skin's sensory afferent fibers so that they can affect the human body and mind. The intermittent pressure applied during massage can increase blood circulation and lymphatic drainage which causes changes in heart rate and blood pressure, which has an impact on relaxing the body and mind, as well as reducing pain and psychological disorders (Sarli and Sari, no date; Jahdi et al., 2016).

Massage therapy has been shown to reduce psychological disorders in postpartum mothers such as anxiety (Jahdi et al., 2016), depression (Sarli and Sari, no date), stress scores (Jung et al., 2017), to decrease levels of the body's cortisol hormone (Agustina, Hadi and Widyawati, 2016) significantly compared to the control group.

The administration of aromatherapy can reduce the release of cortisol and increase serotonin secretion which has an impact on reducing anxiety (Kianpour et al., 2016). The essential oils used for aromatherapy increase relaxation by stimulating the hypothalamus and activating the parasympathetic nervous system (Asazawa et al., 2018).

Aromatherapy has been shown to induce relaxation in postpartum mothers (Asazawa et al., 2018), reducing depression scores (Kianpour et al., 2016; Conrad, Conrad and Adams, 2018), anxiety scores (Kianpour et al., 2016), and causes an increase in positive mood (Varizi et al., 2017).

Research articles on holistic therapy to reduce the psychological disorders of postpartum mothers still have several limitations, such as the absence of a randomization when selecting samples and did not involve interfering variables within the study. However, research articles on holistic therapy to reduce the psychological disorders of postpartum mothers can be used as a basis for carrying out holistic therapy in postpartum mothers as well as development materials for further research. 


\section{STRADA Jurnal Ilmiah Kesehatan}

DOI: $10.30994 /$ sjik.v9i2.524

ISSN: 2252-3847 (print); 2614-350X (online)

Vol.9 No.2 November 2020 Page.1708-1717

\section{CONCLUSION}

Holistic therapies such as mindfulness, massage, and aromatherapy have been shown to be beneficial in reducing psychological disorders such as anxiety and depression in postpartum mothers which have an impact on increased relaxation and positive mood.

\section{REFERENCES}

Adedinsewo, D. A. et al. (2014a) 'Human Lactation Maternal Anxiety and Breastfeeding':, Journal of Human Lactation, 30(1). doi: $10.1177 / 0890334413504244$. https://journals.sagepub.com/doi/10.1177/0890334413504244

Adedinsewo, D. A. et al. (2014b) 'Maternal Anxiety and Breastfeeding: Findings from the MAVAN ( Maternal Adversity, Vulnerability and Neurodevelopment ) Study', Journal of Human Lactation, 30(1). doi: 10.1177/0890334413504244. https://www.ncbi.nlm.nih.gov/pubmed/24065719

Agustina, C. S., Hadi and Widyawati, M. N. (2016) 'aromatherapy massage as an alternative in reducing cortisol level and enhancing breastmilk production on primiparous postpartum women in semarang', 4th Asian Academic Society International Conference, pp. 381-388. http://aasic.org/proc/aasic/article/view/203

Asazawa, K. et al. (2018) 'Effectiveness of Aromatherapy Treatment in Alleviating Fatigue and Promoting Relaxation of Mothers during the Early Postpartum Period', pp. 196-209. doi: 10.4236/ojn.2018.83017. https://www.scirp.org/journal/paperinformation.aspx? paperid=83346

Conrad, P., Conrad, P. and Adams, C. (2018) 'The effects of clinical aromatherapy for anxiety and depression in the high risk postpartum woman - A pilot study Complementary Therapies in Clinical Practice The effects of clinical aromatherapy for anxiety and depression in the high risk postpartum woman e A pilot study', Complementary Therapies in Clinical Practice. Elsevier Ltd, (August 2012), pp. 510. doi: 10.1016/j.ctcp.2012.05.002. https://pubmed.ncbi.nlm.nih.gov/22789792/

Cook-Cottone, C. P. (2017) Mindfulness and Yoga in Schools: a guide for teachers and practitioners. I. Edited by D. Riegert. New York: Springer Publishing Company.

Dimidjian, S. et al. (2014) 'An open trial of mindfulness-based cognitive therapy for the prevention of perinatal depressive relapse / recurrence'. doi: 10.1007/s00737-0140468-x.

Fallon, V. et al. (2016) 'Postpartum Anxiety and Infant-Feeding Outcomes : A Systematic Review', Journal of Human Lactation, 32(4). doi: 10.1177/0890334416662241. https://www.ncbi.nlm.nih.gov/pubmed/27565200

Field, T. (2018) 'Postnatal anxiety prevalence, predictors and effects on development: A narrative review', 51(February), pp. 24-32. doi: 10.1016/j.infbeh.2018.02.005. https://www.sciencedirect.com/science/article/abs/pii/S0163638317302357

Gu, J. et al. (2015) 'Clinical Psychology Review How do mindfulness-based cognitive therapy and mindfulness-based stress reduction improve mental health and wellbeing? A systematic review and meta-analysis of mediation studies', Clinical Psychology Review. Elsevier Ltd, 37, pp. 1-12. doi: 10.1016/j.cpr.2015.01.006. https://www.ncbi.nlm.nih.gov/pubmed/25689576

Hall, H. G., Mckenna, L. G. and Griffiths, D. L. (2012) 'Midwives ' support for Complementary and Alternative Medicine: A literature review', Women and Birth. Australian College of Midwives, 25(1), pp. 4-12. doi: 10.1016/j.wombi.2010.12.005. https://www.womenandbirth.org/article/S1871- 


\section{STRADA Jurnal Ilmiah Kesehatan}

DOI: $10.30994 /$ sjik.v9i2.524

ISSN: 2252-3847 (print); 2614-350X (online)

Vol.9 No.2 November 2020 Page.1708-1717

5192(10)00088-0/pdf

Jahdi, F. et al. (2016) 'The Effect of Slow-Stroke Back Massage on the Anxiety Levels of Iranian Women on the First Postpartum Day', 18(8). doi: 10.5812/ircmj.34270.Research.

https://www.ncbi.nlm.nih.gov/pmc/articles/PMC5068252/\#: :text=The\%20aim\%20 of $\% 20$ this \%20study,postpartum\%20day\%20in\%20primiparous\%20women.

Jordan, R. G., Farley, C. L. and Grace, K. T. (2019) Prenatal and Postnatal Care. 2nd edn. Edited by R. G. Jordan. Hoboken, USA: Wiley.

Jung, G. et al. (2017) 'Effects of Meridian Acupressure Massage on Body Composition, Edema, Stress, and Fatigue in Postpartum Women', The Journal of Alternative and Complementary Medicine, 00(00), pp. 1-7. doi: 10.1089/acm.2016.0362. https://pubmed.ncbi.nlm.nih.gov/28714769/

Kementerian Kesehatan, R. (2013) Buku Saku Pelayanan Kesehatan Ibu Di Fasilitas Kesehatan Dasar Dan Rujukan. Jakarta: Kementerian Kesehatan RI.

Kianpour, M. et al. (2016) 'Effect of lavender scent inhalation on prevention of stress, anxiety and depression in the postpartum period', pp. 197-201. doi: 10.4103/17359066.178248. https://www.ncbi.nlm.nih.gov/pmc/articles/PMC4815377/

Luberto, C. M., Park, E. R. and Goodman, J. H. (2018) 'Postpartum outcomes and formal mindfulness practice in mindfulness based cognitive therapy for perinatal women', HHS Public Access, 9(3), pp. 850-859. doi: 10.1007/s12671-017-08258.Postpartum. https://pubmed.ncbi.nlm.nih.gov/30079120/

María, A. et al. (2012) 'Coping and adaptation process during puerperium', Colombia Medica, 43(2).

Papathanasiou, I., Sklavou, M. and Kourkouta, L. (2013) 'Holistic nursing care: theories and perspectives', American Journal of Nursing Science, 2(1), pp. 1-5. doi: 10.11648/j.ajns.20130201.11. https://www.researchgate.net/profile/Ioanna_Papathanasiou/publication/235759117_ Holistic_Nursing_Care_Theories_and_Perspectives/links/02bfe513359fc613bc0000 00/Holistic-Nursing-Care-Theories-and-Perspectives.pdf

Sarli, D. and Sari, F. N. (no date) 'The Effect of Massage Therapy With Effleurage Techniques as A Prevention of Baby Blues Prevention on Postpartum Mother', 1(3), pp. 15-21. doi: 10.31632/ijalsr.2018v01i03.003. http://ijalsr.org/index.php/journal/article/view/24

Sheydaei, H. et al. (2017) 'The effectiveness of mindfulness training on reducing the symptoms of postpartum depression', Electronic Physician, 9(July), pp. 4753-4758. https://www.ncbi.nlm.nih.gov/pmc/articles/PMC5586989/

Shorey, S. et al. (2018) 'Prevalence and incidence of postpartum depression among healthy mothers: A systematic review and meta-analysis', Journal of Psychiatric Research. Elsevier, 104(August), pp. 235-248. doi: 10.1016/j.jpsychires.2018.08.001. https://pubmed.ncbi.nlm.nih.gov/30114665/

Shulman, B. et al. (2017) 'Feasibility of a Mindfulness-Based Cognitive Therapy Group Intervention as an Adjunctive Treatment for Postpartum Depression and Anxiety', Journal of Affective Disorders. Elsevier B.V. doi: 10.1016/j.jad.2017.12.065. https://pubmed.ncbi.nlm.nih.gov/29653295/

Varizi, F. et al. (2017) 'Effect of Lavender Oil Aroma in the Early Hours of Postpartum Period on Maternal Pains, Fatigue, and Mood: A Randomized Clinical Trial', International Journal of Preventive Medicine, 8(29), pp. 1-7. doi: 10.4103/ijpvm.IJPVM. https://www.ncbi.nlm.nih.gov/pmc/articles/PMC5439291/ 